\title{
SEMINAR KKLP YAPTI JENEPONTO DESA
}

\author{
RAMBA \\ EKA SERLI PRATIWI \\ 9173770410318 \\ ekaserlipratiwii@gmail.com
}

1. Bentuk Kegiatan

> Mengadiri seminar desa yang dilakukan oleh KKLP

Yapti Jeneponto di desa Ramba

2. Lokasi

Aula Wisata Alam Bossolo Rumbia

3. Hari/Tanggal dan Waktu

> Kamis 24 september 2020 pukul 16: 00 - selesai

4. Peserta Yang Dilibatkan

> Dosen STIE STKIP Yapti Jeneponto

> Aparat desa Ramba

> Karang Taruna desa Ramba

> Masyarakat desa Ramba

> Mahasiswa KKLP Yapti jeneponto

> Mahasiswa STIE AMKOP Makassar

5. Alasan Diadakannya

Alasan diadakannya kegiatan ini adalah untuk memaparkan program kerja yang aakan di lakukan oleh Mahasiswa KKLP Yapti Jenepontodi desa Ramba

6. Tujuan dan Manfaat

> Tujuan dan Manfaatnya untuk memberitahukan masyarakat desa Ramba mengenai program kerja yang akan dilaksanakan selama mereka Ber KKLP di desa Ramba. Di harapkan dengan kehadiran mereka di tengah-tengah masyarakat dapat membantu kegiatan 
desa dan berinovasi produk yang dapat bernilai ekonomi

7. Deskripsi Kegiatan

Kegiatan ini dilaksanakan dengan tujuan untuk memaparkan proker yang akan mereka lakukan. Kegiatan dilaksanakan Ba'da Ashar sampai selesai. Kegiatan ini dihadiri oleh tokoh-tokoh Masyarakat, Mahasiswa dan beberapa Dosen. 